\title{
Effect of fiber content and their hybridization on bending and torsional strength of hybrid epoxy composites reinforced with carbon and sugar palm fibers
}

\author{
N.M.Z. Nik Baihaqi ${ }^{1}{ }^{1}$, A. Khalina ${ }^{1), 2), ~ *) ~(O R C I D ~ I D ~ 0000-0002-5370-6336), ~ N . ~ M o h d ~ N u r a z z i ' ~}{ }^{3)}(0000-0001-7697-0511)$, \\ H.A. Aisyah ${ }^{2)}(0000-0002-4127-4740)$, S.M. Sapuan ${ }^{1), 2)}{ }^{(0000-0003-0627-7951), ~ R . A . ~ I l y a s ~}{ }^{1), 2)}$ (0000-0001-6622-2632)
}

DOI: dx.doi.org/10.14314/polimery.2021.1.5

\begin{abstract}
This study aims to investigate the effect of fiber hybridization of sugar palm yarn fiber with carbon fiber reinforced epoxy composites. In this work, sugar palm yarn composites were reinforced with epoxy at varying fiber loads of 5, 10, 15, and $20 \mathrm{wt} \%$ using the hand lay-up process. The hybrid composites were fabricated from two types of fabric: sugar palm yarn of 250 tex and carbon fiber as the reinforcements, and epoxy resin as the matrix. The ratios of $85: 15$ and $80: 20$ were selected for the ratio between the matrix and reinforcement in the hybrid composite. The ratios of $50: 50$ and $60: 40$ were selected for the ratio between sugar palm yarn and carbon fiber. The mechanical properties of the composites were characterized according to the flexural test (ASTM D790) and torsion test (ASTM D5279). It was found that the increasing flexural and torsion properties of the non-hybrid composite at fiber loading of $15 \mathrm{wt} \%$ were $7.40 \%$ and $75.61 \%$, respectively, compared to other fiber loading composites. For hybrid composites, the experimental results reveal that the highest flexural and torsion properties were achieved at the ratio of 85/15 reinforcement and 60/40 for the fiber ratio of hybrid sugar palm yarn/carbon fiber-reinforced composites. The results from this study suggest that the hybrid composite has a better performance regarding both flexural and torsion properties. The different ratio between matrix and reinforcement has a significant effect on the performance of sugar palm composites. It can be concluded that this type of composite can be utilized for beam, construction applications, and automotive components that demand high flexural strength and high torsional forces.
\end{abstract}

Keywords: sugar palm fiber, sugar palm yarn, carbon fiber, hybrid composites, epoxy resin, flexural properties, torsion properties.

\section{Wpływ zawartości i hybrydyzacji włókien na wytrzymałość na zginanie oraz skręcanie hybrydowych kompozytów epoksydowych wzmocnionych włóknami węglowymi i włóknami palmy cukrowej}

Streszczenie: Zbadano wpływ dodatku przędzy z włókien palmy cukrowej o grubości 250 tex na wytrzymałość kompozytów epoksydowych wzmocnionych włóknem węglowym. Sumaryczna zawartość włókien w osnowie żywicy epoksydowej była równa 5, 10, 15 i 20\% mas., a stosunek udziału przędzy palmy cukrowej do włókna węglowego wynosił 50 : 50 i 60 : 40. Właściwości mechaniczne kompozytów hybrydowych o stosunku osnowy do wzmocnienia $85: 15$ i $80: 20$ scharakteryzowano na podstawie testów na zginanie i skręcanie. Stwierdzono, że wytrzymałość na zginanie i skręcanie kompozytu epoksydowego z udziałem $15 \%$ mas. przędzy palmy cukrowej była większa niż pozostałych kompozytów niehybrydowych i wynosiła, odpowiednio, 7,40\% i 75,61\%. W wypadku kompozytów hybrydowych stwierdzono, że najlepszą wytrzymałość na zginanie i skręcanie wykazywały kompozyty z udziałem 15\% mas. wzmocnienia w stosunku 60 : 40 włókien palmy cukrowej do włókien węglowych. Różna zawartość włókien wzmacniających w osnowie epoksydowej miała istotny wpływ na właściwości wytwarzanych kompozytów. Kompozyty tego rodzaju można wykorzystać do budowy elementów konstrukcyjnych i motoryzacyjnych, o dużej wytrzymałości na zginanie i działanie sił skręcających.

Słowa kluczowe: włókno palmy cukrowej, włókno węglowe, kompozyty hybrydowe, żywica epoksydowa, wytrzymałość na zginanie, wytrzymałość na skręcanie.

1) Universiti Putra Malaysia, Faculty of Engineering, 43400 Serdang, Selangor, Malaysia.

2) Universiti Putra Malaysia, Institute of Tropical Forestry and Forest Products (INTROP), 43400 Serdang, Selangor, Malaysia.

3) National Defence University of Malaysia, Center for Defence Foundation Studies, Kem Sungai Besi, 57000 Kuala Lumpur, Malaysia.

*) Author for correspondence: khalina.upm@gmail.com 
Natural fibers have been widely used as an alternative and effective reinforcement in polymer matrices. Fillers, in the form of fibers or particles, are fabricated with polymers to obtain products with desired thermal, mechanical, and electrical properties. The properties of the composite materials are mainly dependent on their respective fiber properties. Other than that, factors affecting the properties include microstructural parameters such as fiber diameter, fiber length, fiber distribution, fiber orientation, volume fraction of the fibers, and packing arrangement of the fibers [1]. In structural applications, fiber-reinforced composites have gained a lot of market potential for their varied uses. However, this market growth is limited due to the lack of toughness of fiber-reinforced composites. The mechanical properties of natural fiber-reinforced composites are significantly improved by the incorporation of synthetic fibers [2].

Sugar palm (Arenga pinnata) fiber is a waste product of the agricultural industry. It is also agro-waste that can be used as a potential source of reinforcement for various biomaterial applications [3, 4]. Palm sap tapping was popular because the sap was commonly used as the base material for making traditional sugar blocks, also known as gula kabung or gula enau in the Malay language [5]. Its fruits can be processed into pickles, juices, and desserts, and they are usually canned for the food industry. Another important part, besides palm sugar and the fruits, is the black fiber called ijuk. The black fiber has many applications and uses including the manufacturing of brooms, paint brushes, septic tank base filters, clear water filters, door mats, carpets, and ropes for sea cordage [6]. Sugar palm fiber offers high tensile strength (similar to the strength of coir, kenaf, bamboo, and hemp fibers within the range 138.7 to $270 \mathrm{MPa}$ ) that is durable before degradation. It is a fairly durable fibrous material that has a good resistance to sea water and is less affected by heat and moisture damage compared to coir fiber [7, 8]. Many studies have been conducted on the properties of sugar palm fiber-reinforced composites. Sugar palm fibers have an excellent composite potential, unlike other natural fibers such as kenaf, jute, oil palm, sugarcane bagasse, pineapple leaf, and banana pseudo stem fibers [9-15].

Synthetic fibers such as glass fiber, carbon fiber, and Kevlar are man-made fibers that have been used dominantly in the composite industry, especially in aerospace, automotive, and sports equipment. Many studies reveal the promising performance of synthetic fibers as a good mechanical and thermal material enhancer [1619]. Nonetheless, the negative environmental and health effects associated with synthetic fibers have led to the increasing use of natural fibers such as jute, ramie, bamboo, kenaf, oil palm, and wood as promising alternative reinforcements. However, the desired tensile strengths and modulus of glass fibers are visibly much higher than natural fibers [20]. Researchers and engineers are enticed by the numerous merits of natural fibers over synthetic fibers. The escalating use of natural fibers can be ascribed to their availability, processability, renewability, recyclability, and biodegradability [21]. Besides, natural fibers have several advantages such as comparable tensile strength properties, low density, and less energy consumption during processing over synthetic fibers [22]. Despite the advantages of natural fibers, they have major drawbacks such as the ability to absorb water (hydrophilic in nature), strength degradation, lack of thermal stability, and low impact properties [23-25]. These drawbacks can be improved by the following: (i) hybridization either with natural or synthetic fiber [26, 27] and (ii) modification through chemical treatments [28, 29]. Table 1 shows the main comparison between natural fibers and synthetic fibers [30].

T a b l e 1. The comparison of properties between natural fibers and synthetic fibers [30]

\begin{tabular}{l|c|c}
\hline \multicolumn{1}{c|}{ Properties } & Natural fibers & Synthetic fibers \\
\hline Density & Light & $\begin{array}{c}\text { Twice than natural } \\
\text { fibers } \\
\text { Higher than } \\
\text { natural fibers }\end{array}$ \\
$\begin{array}{l}\text { Renewability } \\
\text { Energy } \\
\text { consumption }\end{array}$ & Yes & No \\
$\begin{array}{l}\text { Distribution } \\
\mathrm{CO}_{2} \text { neutral }\end{array}$ & Low & High \\
$\begin{array}{l}\text { Health risk when } \\
\text { inhaled }\end{array}$ & Yide & $\begin{array}{c}\text { High } \\
\text { Disposal }\end{array}$ \\
\hline
\end{tabular}

The development of hybrid composite materials is based on the reinforcement of two or more fibers in a single matrix. Research reveals that the behavior of hybrid composites appears to be the weighted sum of individual components that have a more favorable balance between the advantages and disadvantages in any composite material [31]. Furthermore, the hybridization of different fibers is advantageous because one particular fiber can complement the limitations of another fiber. As a result, it has increased fatigue life, better fracture toughness, lower notch sensitivity, and cost reduction for engineering applications [33-35] compared to single fiber-reinforced composites [32]. The benefits of hybridization compared to composite systems, even if they are only partial, are mainly in terms of ecological and economical effects. Natural fibers are biodegradable and lighter than glass fiber. This feature allows the reduction of fuel use by the automotive and aerospace industry [36].

There are several factors affecting the mechanical properties of hybrid composites, such as hybridization design, fiber volume or weight fraction, nature of the matrix, fiber length, fiber composition, and fiber-matrix interface [34, 37]. One work [38] stated that much research 
reveals that the behavior of hybrid biocomposites is the function of the weighted sum of individual components with a favorable balance between the benefits and drawbacks of composite materials. Several studies also investigated the effect of hybridization between a natural fiber and a synthetic fiber (carbon fiber and glass fiber) in a single matrix [39-45].

The objective of this study is to compare the mechanical properties, i.e., flexural and torsion properties, of nonhybrid sugar palm yarn fiber-reinforced epoxy composites and the effect of the hybridization of sugar palm yarn fiber with carbon fiber-reinforced epoxy composites at different fiber ratios for automotive purposes.

\section{EXPERIMENTAL PART}

\section{Materials}

The sugar palm fiber was purchased from Hafiz Adha Enterprise, Kampung Kuala Jempol, Negeri Sembilan, Malaysia. Then, the yarn sugar palm fiber (250 tex) was obtained using published protocols [46]. The carbon fiber was supplied by Sky Tech Malaysia Sdn. Bhd., and the epoxy resin (RTM grade, 40\% styrene content, density of $1.025 \mathrm{~g} / \mathrm{cm}^{3}$ ) was purchased from CCP Composites Resins Malaysia Sdn. Bhd. Table 2 shows the physical and mechanical properties of the materials used.

\section{Preparation process of the composites}

The sugar palm yarn with a linear density of 250 tex was produced by the spinning process, which was in accordance with the procedures specified in previous studies [46, 48]. The composite was prepared according to the mix ratio from the instruction labels. The mix ratio of $3 \mathrm{~A}$ : $1 \mathrm{~B}$ was used, where $\mathrm{A}$ is for epoxy and $\mathrm{B}$ is for hardener. The mixed resin was poured over the fibers and cured at room temperature for $24 \mathrm{~h}$.

For the fabrication of hybrid composites, the ratios between matrix and reinforcement of $85: 15$ and $80: 20$ were selected. The ratios of reinforcement between the sugar palm yarn fiber and carbon yarn fiber of $60: 40$ and $50: 50$ were selected. The carbon fiber was manually wrapped in the PVC pipe and the bundle of sugar

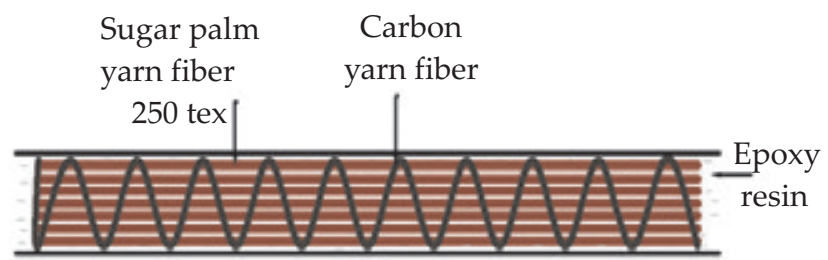

Fig. 1. Schematic diagram for the position of carbon yarn fiber wrapped around the sugar palm yarn fiber

palm yarn fiber as per weight percentage (wt \%) (Fig. 1). Figure 2 shows the overall preparation process of the composites.

\section{Methods of testing}

The flexural test was performed using the three-point bending method using an Instron 3365 test machine according to ASTM D790. The length and diameter of the cylindrical samples were 120 and $16 \mathrm{~mm}$, respectively. The crosshead speed was set at $5 \mathrm{~mm} / \mathrm{min}$ and the support span-to-depth ratio was $16: 1$. The coefficient of variance $(\mathrm{COV})$ was calculated using Eq. (1).

$$
\operatorname{COV}=\frac{\text { standard deviation }}{\text { mean of flexural strength }} \cdot 100 \%
$$

The torsional test was conducted according to ASTM D5279 using the torsion test machine with the capacity of $50 \mathrm{Nm}$. The length and diameter of the samples were 120 and $16 \mathrm{~mm}$, respectively. A hexagonal socket was used to fix the sample to the torsion test machine. The sample was rotated by the spindle, and the values of torque and angle were recorded at the same time. Then, the shear modulus of the sample was calculated using Eq. (2).

$$
G=\frac{T l}{J^{T} \varphi}
$$

where: $G$ - the shear modulus or modulus of elasticity, $T-$ the applied torque, $l-$ the length of object in which torque is applied, $J^{T}$ - the polar moment of inertia, $\varphi$ - the angle of twist.

T a b l e 2. Physical and mechanical properties of sugar palm fiber [48], carbon fiber [47], and epoxy (EpoxAmite 100 with 102 hardener) composite

\begin{tabular}{l|c|c|c}
\hline \multirow{2}{*}{ Properties } & \multicolumn{2}{c}{ Material } & Epoxy matrix \\
\cline { 2 - 4 } & Sugar palm fiber & Carbon fiber & 1.13 \\
\hline Density, g/cm ${ }^{3}$ & 1.292 & 1.1 to 1.9 & 56.40 \\
Tensile strength, MPa & 156.96 & 4000 & 3.10 \\
Tensile modulus, GPa & 4.96 & 230 to 240 & 1.4 to 1.8 \\
Elongation at break, \% & 7.98 & - & 2.45 \\
Flexural strength, MPa & - & - & 84.25 \\
Flexural modulus, GPa & - & & 2.92 \\
\hline
\end{tabular}



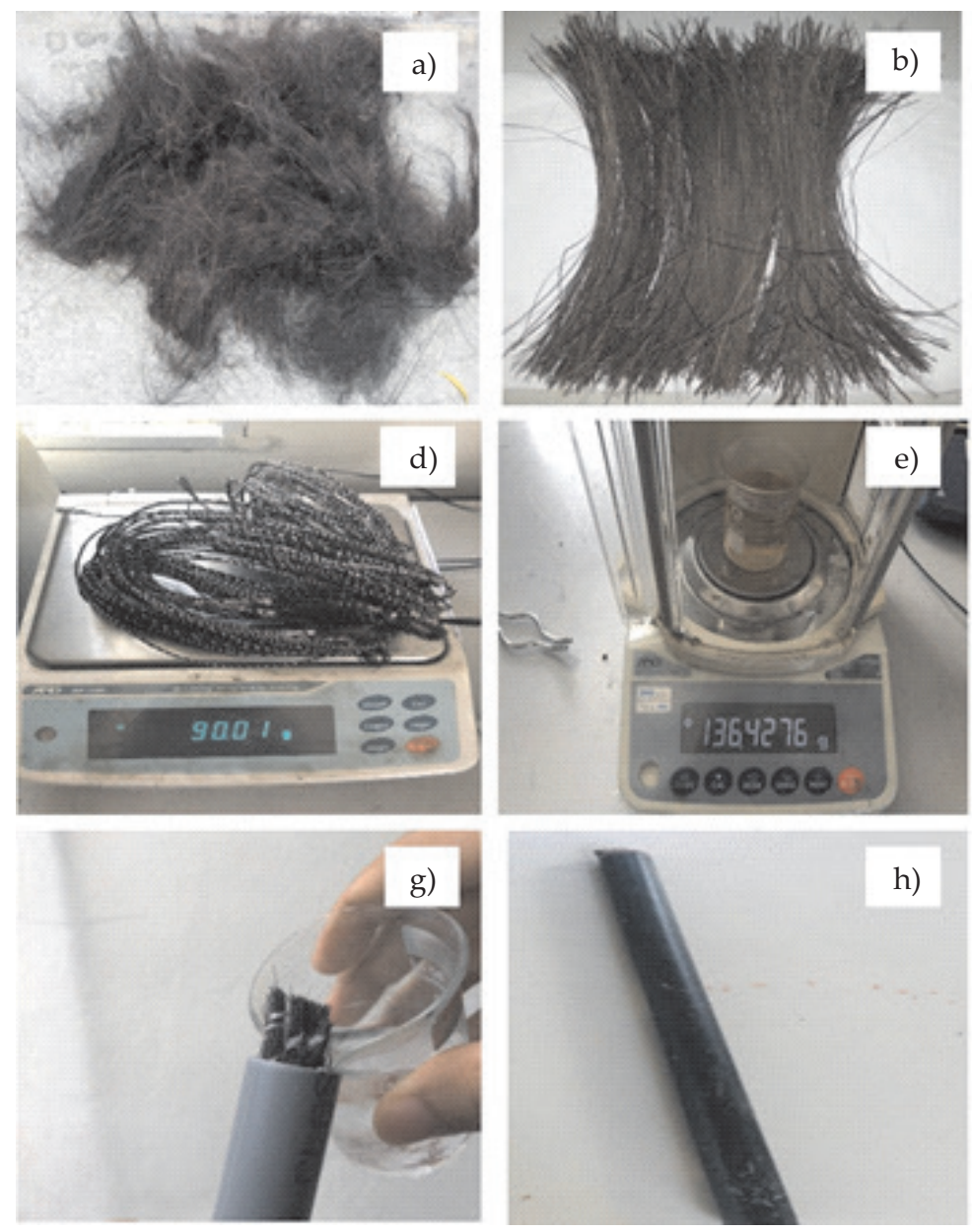

e)
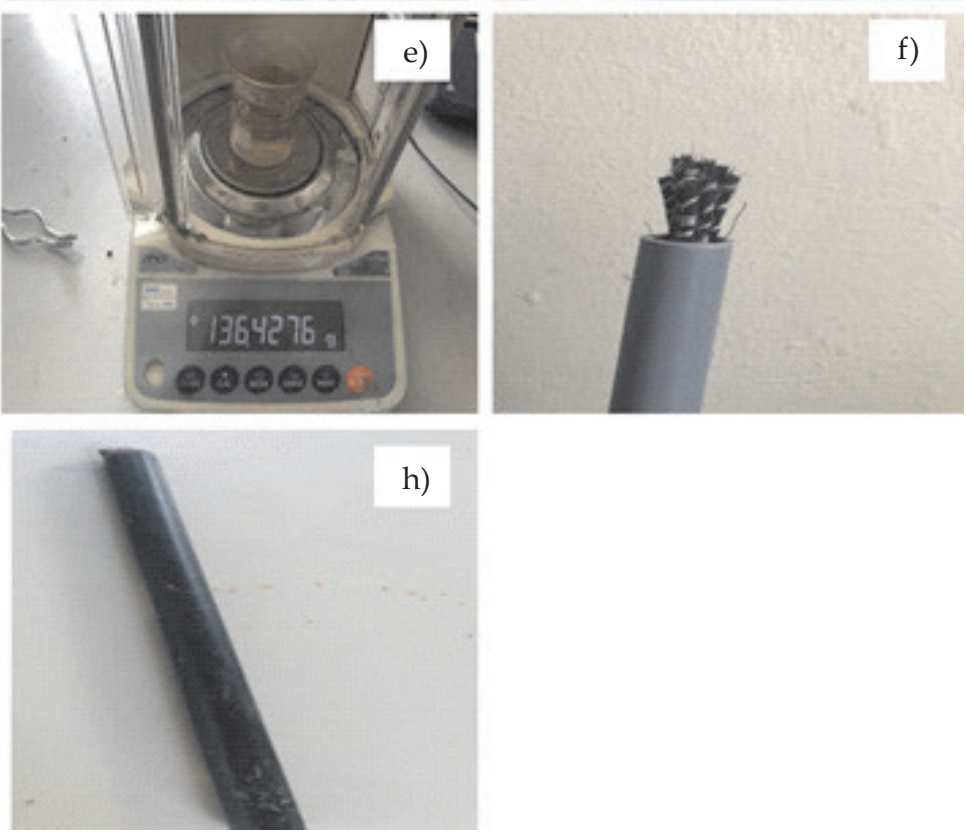

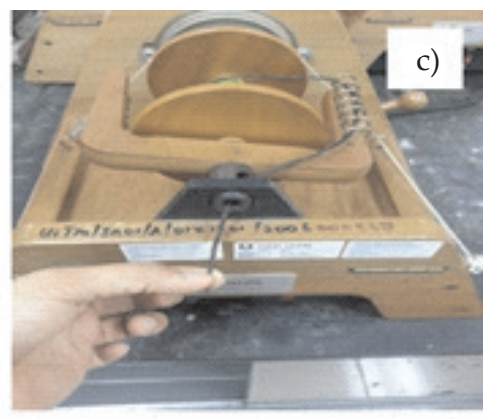

f)

Fig. 2. Photograph of: a) raw sugar palm fiber, b) combed sugar palm fiber, c) spinning process [44, 49], d) sugar palm yarn fiber, e) weighed epoxy resin, f) inserted sugar palm yarn fiber into the PVC pipe, g) the pouring process, h) cured composite

\section{RESULTS AND DISCUSSION}

\section{Flexural properties}

Figure 3 shows the flexural results for the non-hybrid composites. The figure shows an increasing trend up to $15 \mathrm{wt} \%$ of sugar palm yarn fiber loading before it declines at $20 \mathrm{wt} \%$ of fiber loading. The highest flexural strength recorded was $87 \mathrm{MPa}$ and the flexural modulus recorded was $3.3 \mathrm{GPa}$ at $15 \mathrm{wt} \%$. The higher value of flexural strength obtained at 15 wt \% fiber loading composite was because the composites can withstand more load with an increase of corresponding fiber volume in the composite. Higher numbers of fibers correspond to an effective stress transfer within the matrix. Thus, a composite with higher fiber loading could transfer more stress. In addition, the increment was due to the better interfacial adhesion (wettability) between the sugar palm yarn fiber with the epoxy matrix. One publication [50] highlights factors that affect flexural strength such as interfacial strength, degree of cure, and fiber volume fraction that are more complex than a direct correlation. During the flexural test, the vertical load is transferred from the center top surface of the specimen to the bottom surface. The top surface was under compression deformation while the bottom surface was under tensile deformation.

The flexural strength and flexural modulus decreased at $20 \mathrm{wt} \%$ of fiber loadings with $85 \mathrm{MPa}$ and $3.1 \mathrm{GPa}$, which are equivalent to $2.3 \%$ and $6 \%$, respectively. The increased fiber-fiber interactions and the inefficiency of the matrix to penetrate and cover the fibers could result in a low stress transfer mechanism [46]. Lower wetting properties were observed due to the large amount of sugar palm fibers that resulted in less resin penetration. Besides, the low contact area between the matrix with the sugar palm yarn fiber is due to the higher packing effect between the fiber that reduces the flexural properties.

Generally, lower coefficient of variance $(\mathrm{COV})$ reflects less variation in the results; thus, it has higher consistency and reliability [11]. Based on the COV result shown in Table 3, the fiber loading at $15 \mathrm{wt} \%$ yielded the lowest COV of $8.84 \%$. This result suggests that the fiber loading produced the most consistent and uniform stress transferred from the matrix to the fibers during the applied stress. The highest COV of $21.72 \%$ was obtained from $20 \mathrm{wt} \%$ of fiber loading. It is most difficult to control the fabrication process of the highest fiber loading due to the low wettability between the fiber and the matrix. Hence, it leads to a difficult and inefficient stress transfer. 
$\mathrm{T}$ a b l e 3. Flexural strength $\mathrm{COV}$ of the composites

\begin{tabular}{l|c|c}
\hline \multicolumn{2}{|c|}{ Sample } & COV, \% \\
\hline \multirow{4}{*}{ Non-hybrid } & $5 \mathrm{wt} \%$ & 14.30 \\
composites & $10 \mathrm{wt} \%$ & 12.19 \\
& $15 \mathrm{wt} \%$ & 8.84 \\
& $20 \mathrm{wt} \%$ & 21.72 \\
\hline \multirow{4}{*}{ Hybrid composites } & $15 \mathrm{wt} \%-50: 50$ & 16.73 \\
& $15 \mathrm{wt} \%-60: 40$ & 14.24 \\
& $20 \mathrm{wt} \%-50: 50$ & 18.21 \\
& $20 \mathrm{wt} \%-60: 40$ & 18.49 \\
\hline
\end{tabular}

The difference between the highest and the lowest $\mathrm{COV}$ was $12.88 \%$, indicating a significant gap in the precision for flexural strength mean between 15 and $20 \mathrm{wt} \%$. This result can be justified by looking at the fiber weight percentage between the two samples. Based on the results, it

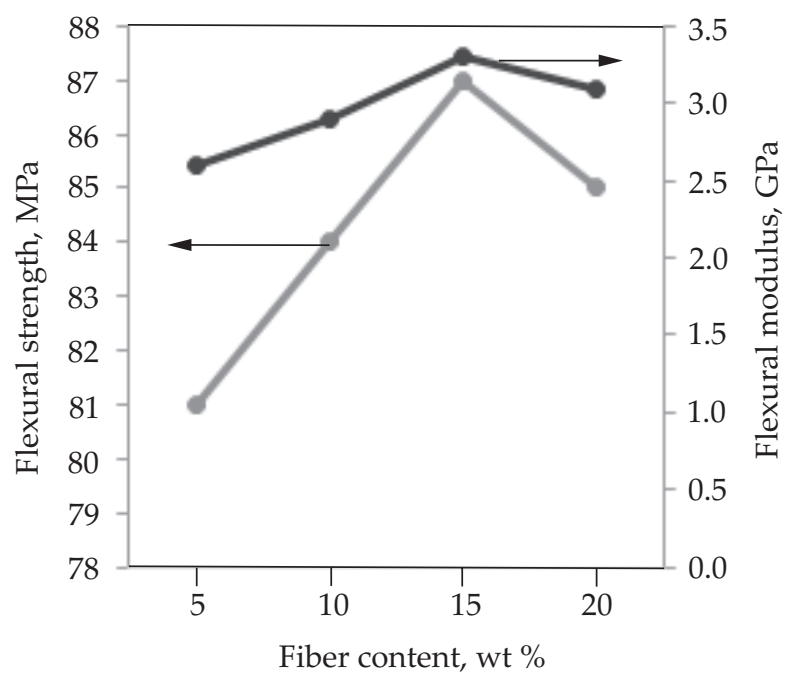

Fig. 3. Flexural properties for non-hybrid epoxy composites reinforced with sugar palm fiber

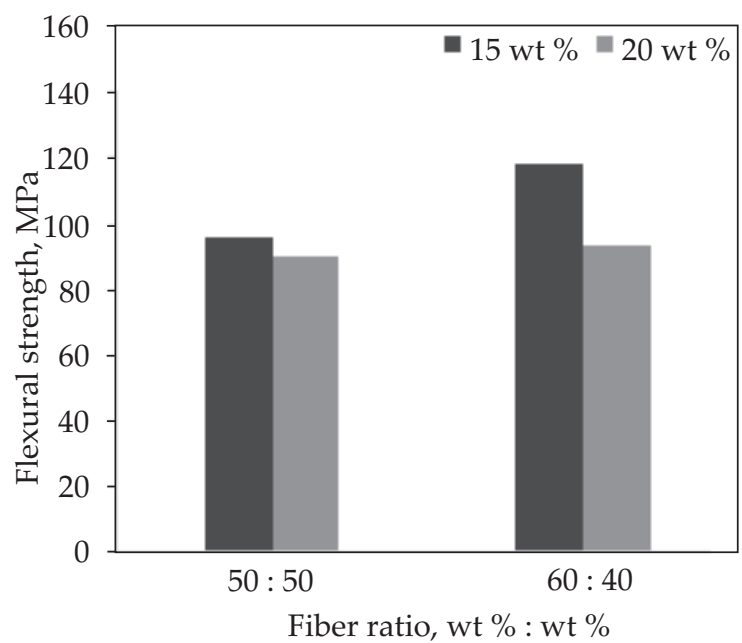

can be deducted that the $15 \mathrm{wt} \%$ sample has a better fiber matrix interaction, which resulted in a more precise and consistent strength throughout the sample.

Figure 4 shows the flexural properties of the hybrid composites. The best flexural properties were achieved from $15 \mathrm{wt} \%$ of reinforcement at the fiber ratio of $60: 40$. The corresponding flexural strength and flexural modulus for the composite sample were $118 \mathrm{MPa}$ and $3.8 \mathrm{GPa}$, respectively. The result shows that the ratio of sugar palm yarn fiber can increase up to $60: 40$ for the flexural strength and flexural modulus. This result is due to the effective layering design and the position of sugar palm yarn fiber at the core or tendon for the composite structure (Fig. 1). The increasing weight percentage of sugar palm yarn fiber loading that is located at the center acted as an efficient rigid filler in absorbing the flexural stress. In the case of hybrid composites, the additional presence of carbon fiber increases the flexural strength by about $35 \%$ and flexural modulus by about $15 \%$. It is influenced by the synergistic effect of carbon fiber that has excellent specific tensile strength and modulus. The lowest $\mathrm{COV}$ was recorded from $15 \mathrm{wt} \%$ reinforcement at $60: 40$ fiber ratio, which is $14.24 \%$. This value indicates that the reinforcement loading and ratio can yield the highest uniformity for flexural strength and flexural modulus mean.

\section{Torsion properties}

Figure 5 shows the results of the torsional forces versus the angle of twist at varying fiber loadings for nonhybrid composites that are obtained from the torsion test machine. The maximum torsional strength on the nonhybrid composites was $41.9 \mathrm{Nm}$ at an angle of twist at $50^{\circ}$ for the composite with $15 \mathrm{wt} \%$ of fiber loading. This result shows that the fiber loading of $15 \mathrm{wt} \%$ is the optimum fiber loading to provide an effective stress transfer and sustain the ultimate shearing force upon the increasing of angle of twist. This also could be due to the

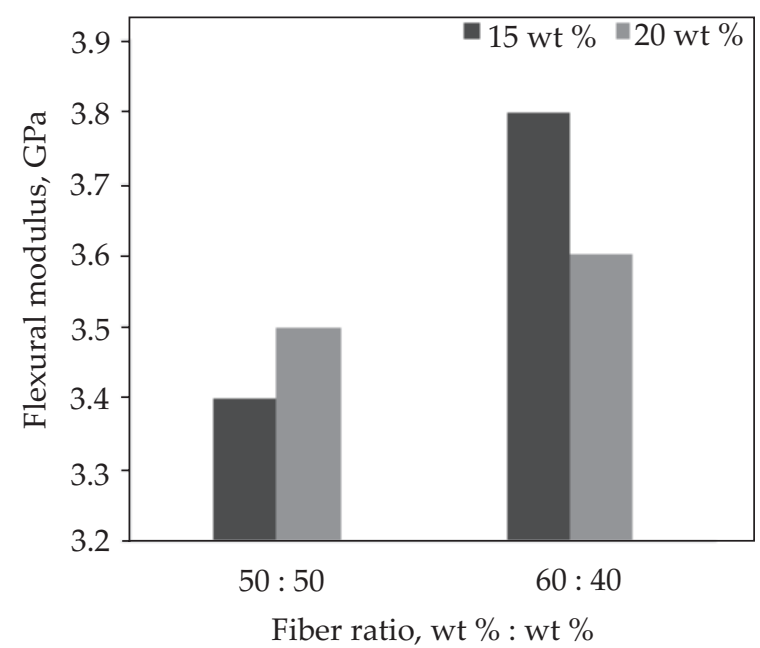

Fig. 4. Flexural properties for hybrid composites 


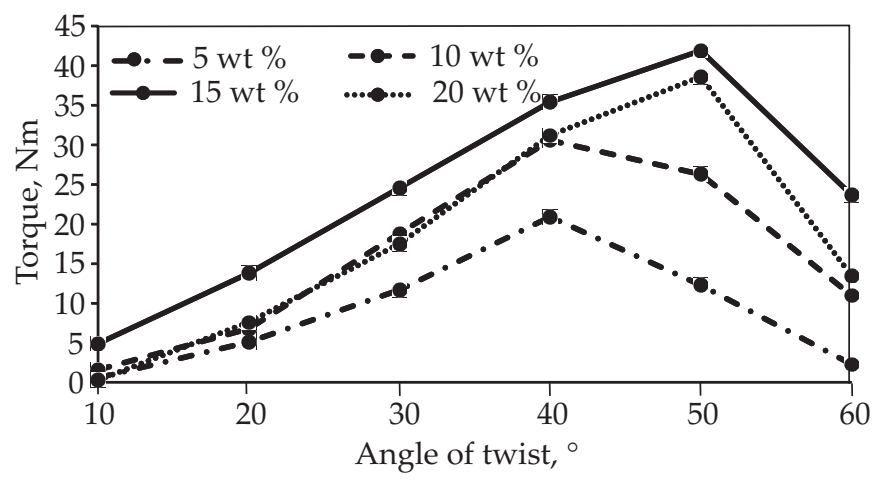

Fig. 5. Torsion properties of the non-hybrid epoxy composites reinforced with sugar palm fiber

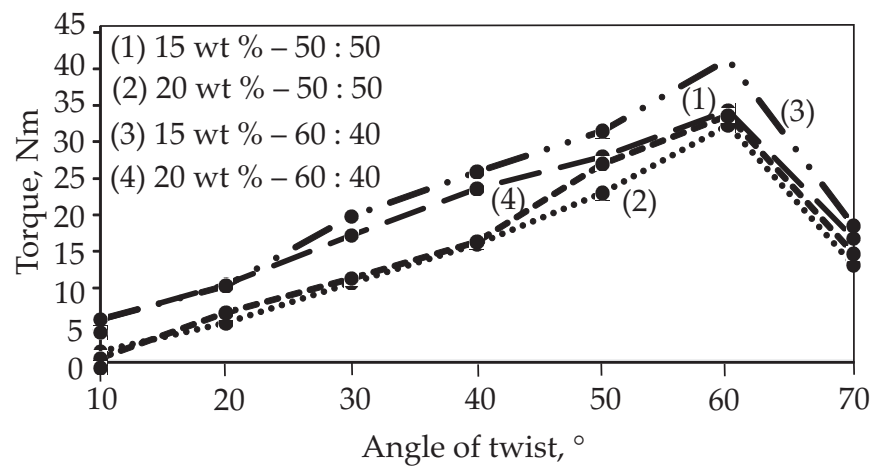

Fig. 6. Torsion properties of the hybrid composite

excellent wettability and contact area between the sugar palm yarn fiber with the epoxy matrix, hence improving the stress mechanism. When the fiber loading is above $20 \mathrm{wt} \%$, the torsional strength decreased to $7.88 \%$ at $50^{\circ}$ angle of twist. This result might be due to the high packing arrangement of sugar palm yarn fiber that leads to excessive fiber-fiber interactions. Hence, it reduces the effectiveness where stress is to be transferred from the matrix to the packed sugar palm yarn fibers.

The optimum angle of twist was at $50^{\circ}$ for 15 and $20 \mathrm{wt} \%$ of fiber loading composites, where the torsional strength dropped at $60^{\circ}$ angle of twist. The twisting of up to $60^{\circ}$ of composites caused fiber compactness and increased the fiber-fiber surface contact. As a result, the effectiveness of the stress transfer mechanism from the matrix to the fibers resisted, and it was difficult to maintain the stability of the composite structure stiffness, which leads to a reduced torsional strength. The optimum angle of twist was at $50^{\circ}$ for 10 and $20 \mathrm{wt} \%$. The stress was transferred to the rich resin area, which was brittle and not efficiently supported by the sugar palm yarn fiber as a result of the reinforcement upon the increased angle of twist. Figure 6 presents the torsional properties of hybrid composites at varied angles of twist. The maximum torsional strength for hybrid composites was $41.3 \mathrm{Nm}$ at $15 \mathrm{wt} \%$ of reinforcement with the fiber ratio of $60: 40$. The extended failure for all composites was up to $60^{\circ}$ angle of twist with the addition of carbon fiber (Fig. 7). This situation happened due to the superior strength and modulus of carbon fibers that can main-

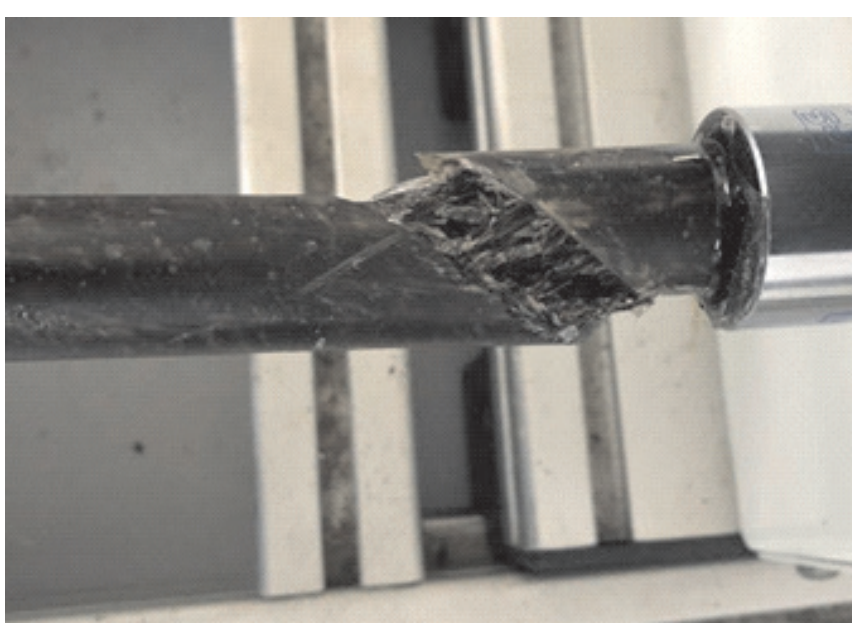

Fig. 7. The failure test result of the non-hybrid epoxy composites reinforced with $20 \mathrm{wt} \%$ of sugar palm fiber

tain the stability of the circular position until deformation occurs.

The shear modulus is defined as rigidity, and it is a measure for the ability of a material to resist transverse deformations and elastic behavior for deformations after the material returns to its original structure. Large shearing forces can lead to flow and permanent deformation and failure. Table 4 presents the results for the shear modulus of the hybrid composites. The shear modulus for non-hybrid and hybrid samples was reduced when the angle of twist was increased.

$\mathrm{T} \mathrm{a} \mathrm{b} 1$ e 4 . Shear modulus of composites at $50^{\circ}$ and $60^{\circ}$ angle of twist

\begin{tabular}{l|c|c|c}
\hline \multicolumn{2}{c|}{ Sample } & $\begin{array}{c}\text { Shear } \\
\text { modulus at } \\
50^{\circ}, \mathrm{GPa}\end{array}$ & $\begin{array}{c}\text { Shear } \\
\text { modulus at } \\
60^{\circ}, \mathrm{GPa}\end{array}$ \\
\hline \multirow{3}{*}{$\begin{array}{l}\text { Non-hybrid } \\
\text { composites }\end{array}$} & $5 \mathrm{wt} \%$ & 0.263 & 0.041 \\
& $10 \mathrm{wt} \%$ & 0.563 & 0.196 \\
& $15 \mathrm{wt} \%$ & 0.897 & 0.423 \\
& $20 \mathrm{wt} \%$ & 0.826 & 0.241 \\
\hline \multirow{3}{*}{$\begin{array}{l}\text { Hybrid } \\
\text { composites }\end{array}$} & $15 \mathrm{wt} \%-50: 50$ & 0.599 & 0.612 \\
& $15 \mathrm{wt} \%-60: 40$ & 0.674 & 0.737 \\
& $20 \mathrm{wt} \%-50: 50$ & 0.492 & 0.576 \\
& $20 \mathrm{wt} \%-60: 40$ & 0.578 & 0.599 \\
\hline
\end{tabular}

\section{CONCLUSIONS}

- The higher flexural strength and flexural modulus of non-hybrid composites were achieved at $15 \mathrm{wt} \%$ of sugar palm yarn fiber loading with $87 \mathrm{MPa}$ and $3.3 \mathrm{GPa}$, respectively. For the hybrid composite, $15 \mathrm{wt} \%$ of reinforcement with the ratio of $60: 40$ revealed the highest flexural strength and flexural modulus, which were $118 \mathrm{MPa}$ and $3.8 \mathrm{GPa}$, respectively.

- The higher torque at $50^{\circ}$ angle of twist and shear modulus were achieved at $15 \mathrm{wt} \%$ of sugar palm yarn fiber loading with $41.9 \mathrm{Nm}$ and $0.897 \mathrm{GPa}$, respectively. 
For the hybrid composite, $15 \mathrm{wt} \%$ of reinforcement at the ratio of $60: 40$ reveals the highest torque value of $41.4 \mathrm{Nm}$ at $60^{\circ}$ angle of twist and shear modulus of 0.737 GPa.

\section{ACKNOWLEDGMENTS}

The authors wish to thank Universiti Putra Malaysia (UPM) for providing research grants (GP-IPB) with the project number GP-IPB/2014/9441502 and excellent facilities.

\section{REFERENCES}

[1] Paul S.A., Boudenne A., Ibos L. et al.: Composites Part A: Applied Science and Manufacturing 2008, 39 (9), 1582. https://doi.org/10.1016/j.compositesa.2008.06.004

[2] Zin M.H., Abdan K., Norizan M.N.: "Structural Health Monitoring of Biocomposites, FibreReinforced Composites and Hybrid Composites" Woodhead Publishing, 2019. https://doi.org/10.1016/B978-0-08-102291-7.00001-0

[3] Ilyas R.A., Sapuan S.M., Atiqah A. et al.: Polymer Composites 2020, 41 (2), 459. https://doi.org/10.1002/pc.25379

[4] Ilyas R.A., Sapuan S.M., Ibrahim R. et al.: Journal of Materials Research and Technology 2019, 8 (3), 2753. https://doi.org/10.1016/j.jmrt.2019.04.011

[5] Ishak M.R., Leman Z., Sapuan S.M. et al.: "Key Engineering Materials", Trans Tech Publications Ltd., 2011, pp. 1153-1158.

https://doi.org/10.4028/www.scientific.net/KEM.471472.1153

[6] Ishak M.R., Sapuan S.M., Leman Z. et al.: Carbohydrate Polymers 2013, 91 (2), 699. https://doi.org/10.1016/j.carbpol.2012.07.073

[7] Maisara A.M.N., Ilyas R.A., Sapuan S.M. et al.: International Journal of Recent Technology and Engineering 2019, 8, 510. https://doi.org/10.35940/ijrte.B1100.0782S419

[8] Nurazzi N.M., Khalina A., Sapuan S.M. et al.: Journal of Mechanical Engineering and Sciences 2017, 11 (2), 2650. https://doi.org/10.15282/jmes.11.2.2017.8.0242

[9] Ilyas R.A., Sapuan S.M., Ishak M.R., Zainudin E.S.: Carbohydrate Polymers 2018, 202, 186. https://doi.org/10.1016/j.carbpol.2018.09.002

[10] Jumaidin R., Sapuan S.M., Jawaid M. et al.: International Journal of Biological Macromolecules 2017, 97, 606. https://doi.org/10.1016/j.ijbiomac.2017.01.079

[11] Sanyang M.L., Sapuan S.M., Jawaid M. et al.: Polymers 2015, 7 (6), 1106. https://dx.doi.org/10.3390/polym7061106

[12] Rashid B., Leman Z., Jawaid M. et al.: International Journal of Precision Engineering and Manufacturing 2016, 17 (8), 1001. https://doi.org/10.1007/s12541-016-0122-9

[13] Atiqah A., Jawaid M., Sapuan S.M. et al.: Composite Structures 2018, 202, 954. https://doi.org/10.1016/j.compstruct.2018.05.009

[14] Ilyas R.A., Sapuan S.M., Ishak M.R. et al.: "Sugar Palm Biofibers, Biopolymers, and Biocomposites", Taylor \& Francis Group, 2018, pp. 189-220.

[15] Mohammed B.R., Leman Z., Jawaid M. et al.: BioResources 2017, 12 (2), 3448.

https://doi.org/10.15376/biores.12.2.3448-3462

[16] Singh T., Gangil B., Patnaik A. et al.: Materials Research Express 2018, 6 (2), 025704. https://doi.org/10.1088/2053-1591/aaee30

[17] Nurazzi N.M., Khalina A., Sapuan S.M., Rahmah M.: Materials Research Express 2018, 5 (4), 045308. https://doi.org/10.1088/2053-1591/aabc27

[18] Zin M.H., Abdan K., Mazlan N. et al.: Composites Part B: Engineering 2019, 177, 107306. https://doi.org/10.1016/j.compositesb.2019.107306

[19] Aisyah H.A., Paridah M.T., Sapuan S.M. et al.: International Journal of Polymer Science 2019, 2019, ID 5258621.

https://doi.org/10.1155/2019/5258621

[20] Mochane M.J., Mokhena T.C., Mokhothu T.H. et al.: Express Polymer Letters 2019, 13 (2), 159. https://doi.org/10.3144/expresspolymlett.2019.15

[21] Sanyang M.L., Sapuan S.M., Jawaid M. et al.: Renewable and Sustainable Energy Reviews 2016, 54, 533 https://doi.org/10.1016/j.rser.2015.10.037

[22] Satyanarayana K.G., Arizaga G.G., Wypych F.: Progress in Polymer Science 2009, 34 (9), 982. https://doi.org/10.1016/j.progpolymsci.2008.12.002

[23] Adekunle K., Cho S.W., Patzelt C. et al:: Journal of Reinforced Plastics and Composites 2011, 30 (8), 685. https://doi.org/10.1177/0731684411405874

[24] Alawar A., Hamed A.M., Al-Kaabi K.: Composites Part B: Engineering 2009, 40 (7), 601. https://doi.org/10.1016/j.compositesb.2009.04.018

[25] Mohd Nurazzi N., Khalina A., Sapuan S.M. et al.: Pertanika Journal of Science \& Technology 2017, 25 (4), 1085.

[26] Nurazzi N.M., Khalina A., Sapuan S.M. et al.: Journal of Materials Research and Technology 2020, 9 (2), 1606. https://doi.org/10.1016/j.jmrt.2019.11.086

[27] Mostafa N.H.: Materials Research Express 2019, 6 (8), 085102. https://doi.org/10.1088/2053-1591/ab21f9

[28] Zin M.H., Abdan K., Norizan M.N., Mazlan N.: Pertanika Journal of Science \& Technology 2018, 26 (1), 161.

[29] Aruchamy K., Subramani S.P., Palaniappan S.K. et al.: Journal of Materials Research and Technology 2020, 9 (1), 718. https://doi.org/10.1016/j.jmrt.2019.11.013

[30] Sreekumar P.A., Thomas S.: "Properties and Performance of Natural-Fibre Composites", Woodhead Publishing, 2008, pp. 67-126. https://doi.org/10.1533/9781845694593.1.67

[31] John M.J., Thomas S.: Carbohydrate Polymers 2008, 71 (3), 343. 
https:/dx.doi.org/10.1016/j.carbpol.2007.05.040

[32] Shahzad A.: Journal of Reinforced Plastics and Composites 2011, 30 (16), 1389. https://doi.org/10.1177/0731684411425975

[33] Venkata Reddy G., Venkata Naidu S., Shobha Rani T.: Journal of Reinforced Plastics and Composites 2008, 27 (16-17), 1789. https://doi.org/10.1177/0731684407087380

[34] Thwe M.M., Liao K.: Composites Part A: Applied Science and Manufacturing 2002, 33 (1), 43. https://doi.org/10.1016/S1359-835X(01)00071-9

[35] Nguyen A.V., Charlet K., Bouzgarrou B.C. et al.: "Key Engineering Materials", Trans Tech Publications Ltd., 2019, pp. 101-106.

https://doi.org/10.4028/www.scientific.net/ KEM.801.101

[36] Vieira C.A.B., Susin S.B., Estevão F. et al.: Materials Research 2009, 12 (4), 433. http://dx.doi.org/10.1590/S1516-14392009000400011

[37] Pothan L.A., Thomas S., George J.: $12^{\text {th }}$ International Conference on Composite Materials, Paris, France 1999, p. 1267.

[38] Mishra S., Mohanty A.K., Drzal L.T. et al.: Composites Science and Technology 2003, 63 (10), 1377. https://doi.org/10.1016/S0266-3538(03)00084-8

[39] Khanam P.N., Khalil H.A., Jawaid M. et al.: Journal of Polymers and the Environment 2010, 18 (4), 727. https://doi.org/10.1007/s10924-010-0210-3

[40] Fiore V., Valenza A., Di Bella G.: Journal of Composite Materials 2012, 46 (17), 2089. https://doi.org/10.1177/0021998311429884
[41] Nor A.F.M., Sultan M.T.H., Jawaid M. et al.: BioResources 2018, 13 (2), 4404. https://doi.orh/10.15378/biores.13.2.4404-4415

[42] Aslan M., Tufan M., Küçükömeroğlu T.: Composites Part B: Engineering 2018, 140, 241. https://doi.org/10.1016/j.compositesb.2017.12.039

[43] Bharath K.N., Sanjay M.R., Jawaid M. et al.: Journal of Industrial Textiles 2019, 49 (1), 3. https://doi.org/10.1177/1528083718769926

[44] Mohd Nurazzi N., Khalina A., Sapuan S.M., Ilyas R.A.: Polimery 2019, 64, 665. https://dx.doi. org/10.14314/polimery.2019.10.3

[45] Manuneethi Arasu P., Karthikayan A., Venkatachalam R.: Polimery 2019, 64, 499. https://dx.doi.org/10.14314/polimery.2019.7.6

[46] Norizan M.N., Abdan K., Salit M.S., Mohamed R.: Journal of Physical Science 2017, 28 (3), 115. https://doi.org/10.21315.jps2017.283.8

[47] Mahjoub R., Yatim J.M., Sam A.R.M., Hashemi S.H.: Construction and Building Materials 2014, 55, 103. https://doi.org/10.1016/j.conbuildmat.2014.01.036

[48] Nurazzi N.M., Khalina A., Chandrasekar M. et al.: Polimery 2020, 65, 115. https://dx.doi.org/10.14314/polimery.2020.2.5

[49] Norizan M.N., Abdan K., Salit M.S., Mohamed R.: Sains Malaysiana 2018, 47 (4), 699. https://dx.doi.org/10.17576/jsm-2018-4704-07

[52] Wulfsberg J., Herrmann A., Ziegmann G. et al.: Procedia Engineering 2014, 81, 1601. https://doi.org/10.1016/j.proeng.2014.10.197

Received 9 VI 2020. 